\title{
The Impact of Global Financial Crisis on the level of non-performing loans in commercial banks in Kosovo
}

Keywords: ROA - Return on Assets, ROE - Return on Equity, C/I - Cost to Income, performance, profit

\section{Introduction}

The banking sector in Kosovo was further consolidated during 2007 and 2008 when new banks entered the market and few other ones merged. This contributed to increased competition and development (Luboteni, 2007).

Commercial banks in Kosovo have undergone major changes since 2000. These changes are as a result of foreign banks, development in regulatory environment, new technology and increased competition. Commercial banks faced increased operating costs as a result of the financial crisis in 2008, and as a result of changes in the banking system, which may have affected banks' loan quality, income and banking liquidity.

Financial crises usually promote preliminary policy and regulation reform in the financial system, due to the fact that financial institutions are more vulnerable during a financial crisis (Bernanke, Gertler, 1989).

In the case of the global financial crisis that began in 2007/2008, the rapid spread of the crisis from individual financial institutions to the whole financial system and then to the real sector, brought an increased attention and commitment to systemic risk (Tarashev,

*Prof. Dr. Gazmend Luboteni, University of Pristina, Kosovo, e-mail: gazmend.luboteni@uni-pr. edu; M.Sc. Arta Hoti, University of Pristina, Kosovo. 
2010). This crisis motivated the reformulation of previous regulatory framework (such as Basel II) and urged reforms in the way of regulation of financial institutions.

This research evaluates the performance of commercial banks in Kosovo during the period 2006-2012 through the method of analysis of financial ratios. The methodology used in the research is the statistical T-test. This is applied to analyze the impact of the recent financial crisis in the performance of commercial banks in Kosovo, focusing mainly on non-performing loans (loan quality of banks). The aim of this research is to analyze the performance of commercial banks in Kosovo, and to analyze the loan quality based mainly on growth trends in non-performing loans and the impact of the global financial crisis in the banking sector in Kosovo.

\section{Literature Review}

This section presents a review of the literature on performance of commercial banks in different countries which are taken as examples for analyzing the performance of commercial banks in the Republic of Kosovo.

There is an increasing amount of research focusing on the global financial crisis of 2008 and the bankruptcy of many well-known global financial institutions. ${ }^{1}$ Measuring banks' performance in general and commercial banks' performance in particular is the topic of many well-established researchers. Most of the published research is based on empirical evidence. (See Oral, Yolalan, 1990; Bonin et al., 2005).

As part of the CAMELS ${ }^{2}$ system, bank regulators apply financial ratios to evaluate the performance of banks. The empirical evidence concerning the application of financial ratios to evaluate the performance of banks includes research authored by Beaver (1966), Altman (1986) and Maishanu (2004).

Reviewing the literature we can conclude that there are two general approaches for measuring bank performance. The first approach is based on accounting data, respectively on main application of banks' financial ratios while the second approach is based on econometric techniques.

Kiyota (2009) undertook a two-phase research to investigate the effectiveness of profit-flow and cost of commercial banks from 29 African countries during the period 2000-2007. This research has applied a SFA approach to evaluate the effectiveness of profits and costs, as well as financial ratios and Tobit regression, in order to offer crosscountry evidence on the performance and efficiency of commercial banks in Africa. The

\footnotetext{
1 e.g. Bank of America, Bear Stearns, Merill Lynch, Citigroup, Lehman Brodhers, etc.

2 C - Capital adequacy, A - Assets, M - Managerial ability, E - Earnings, L- Liquidity, $\mathrm{S}-$ Sensitivity.
} 
findings of this research suggest that foreign banks tend to have better performance compared to local banks, in terms of performance efficiency and also cost efficiency (Kiyota, 2009).

Kirkpatrick (2007) investigated the performance of 89 commercial banks in African countries during the period 1992-1999 and testified that banks on average are 67\% efficient with regard to profit-flow and $80 \%$ efficient in terms of costs (Kirkpatrick, Murinde, Tefula, 2007). Another interesting study on the performance of banks was conducted by Ncube (2009), who has applied a border stochastic model to analyze the efficiency of costs and profit-flow of the 4 major banks and four smaller banks in South Africa. The results of this research indicated that South African banks have improved greatly in cost efficiency during 2005 and 2006, where banks with higher efficiency costs have been more profitable.

\section{The banking sector in the Republic of Kosovo}

In recent years, growth in international financial markets has given the banks the ability to design new products and to offer a wide array of services, but on the other hand we witness an increase in related risks. If until now the biggest banking risk has been the risk that a client or another party can fail to pay back, known as default risk, nowadays banking activity has changed and market environment has become more complex. There is a growing need to manage exposure to other operational and financial risks, because the whole banking activity is focused on analyzing and managing banking risk.

The banking sector in Kosovo consists of commercial banks' activity. During the analyzed period, the number of banks has increased gradually. In 2006 the total number of commercial banks was 6, while in 2013 the number of banks has reached 9, which are: ProCredit Bank (former MEB - Micro Enterprise Bank), Raiffeisen Bank (former American Bank of Kosovo), Bank for Business (former Private Bank for Business), Nova Ljubljanska Banka Pristina (NLB), (established with the merger of two earlier banks Kasa Bank and New Bank of Kosovo - BRK), Commercial Bank, National Commercial Bank-Kosovo Branch (NCB), Turk Economy Bankasi (TEB), Is Bank, and a branch of Komercijalna Banka AD Belgrade that exerts its activity in Mitrovica (Northern) and Gracanica. Seven of these banks have their branches spread in an organized network of subsidiaries across Kosovo. It should be noted that only two banks in Kosovo are banks with local capital (The Bank for Business and the Economic Bank), while other banks are foreign-owned banks. This appears to be a new trend in the Kosovo market. Although commercial banks in Kosovo offer many other services, lending remains their main activity. The demand for cash in a country in transition is significantly larger than the 
cash supply. For this reason the importance of lending remains very high. But it also depends on the existence or absence of a liquid financial market.

The stability and liquidity of a bank depends on, among others, extending loans, meaning loan extension should be on firm basis, in order to preserve the stability and liquidity of the whole banking system. In this sense, the completion of regulatory financial framework is of utmost importance, as well as strict supervision by the Central Bank of the Republic of Kosovo. Another characteristic of the general financial sector in Kosovo is that it is still dominated by the banking sector, which accounts for $70-75 \%$ of total assets of the financial system (RSF, $2010-\mathrm{BQK}){ }^{3}$

Main sources of financing of the banking sector in Kosovo are deposits and local borrowings, which account for $70-80 \%$ of total liabilities. This represents a great advantage for the banking sector of Kosovo, because they are not directly connected to international financial markets and this contributed towards a decreased fallout from the global financial crisis.

As a result of the financial crisis of the year 2008 and in response to it, many countries were forced to increase public spending to influence economic growth and alleviate the effects of the crisis. The global financial crisis of 2008 had a huge impact on all world economies. Many countries entered recession, while in some other countries the economic growth decreased. There were also reactions from central banks, which were obliged to apply expansionary monetary policy and also in order to fulfill their mandate. These measures had a high influence on the elimination of the impact of the crisis, compensating the decline in private sector activity while increasing public sector participation in the economy.

An analysis of the Kosovo's key economic indicators during the period 2006-2012 (as presented in Table 1) shows that there are changes in Kosovo's economy and banking sector. Due to the fact that banks in Kosovo are mostly foreign-owned, the banking systems of countries in which banking groups operated was characterized by slow growth, difficulties in securing financing and portfolio quality deterioration (RSF 2010$\mathrm{CBK}$ ). This has also presented the performance decrease in profitability in the banking sector.

The statistical data (Tables 1 and 2) during 2006-2012 show that the banking sector in Kosovo has been steadily increasing, mainly in loans and deposits. This increase in the banking sector was realized despite the global financial crisis and its worldwide impact.

However, this does not imply that the global financial crisis has not affected the performance and efficiency of these banks.

\footnotetext{
3 bqk-kos.org/repository/docs/2011/Raporti\%20Vjetor\%202010.PDF.
} 
Table 1. The main indicators of the economy of Kosovo during the period 2006-2012

\begin{tabular}{|l|r|r|r|r|r|r|c|}
\hline \multicolumn{1}{|c|}{ Years } & 2006 & 2007 & 2008 & 2009 & 2010 & 2011 & 2012 \\
\hline Real growth of GDP (\%) & 3.4 & 8.2 & 7.2 & 3.5 & 3.2 & 4.5 & 3.8 \\
\hline Inflation (annual average \%) & 3.9 & 44.4 & 9.4 & -2.4 & 3.5 & 7.3 & 2.5 \\
\hline Loans (EUR Mill) & 577 & 820 & 1,183 & 1,289 & 1,459 & 1,698 & 1,763 \\
\hline Deposits (EUR Mill) & 923 & 1,111 & 1,444 & 1,745 & 1,937 & 2,104 & 2,279 \\
\hline Exports (EUR Mill) & 79 & 165 & 199 & 165 & 294 & 313 & 269 \\
\hline Imports (EUR Mill) & 1,315 & 1,576 & 1,928 & 1,936 & 2,145 & 2,479 & 2,489 \\
\hline Government spending (EUR Mill) & 1,043 & 1,003 & 1,301 & 1,307 & 1,504 & 1,698 & 1,783 \\
\hline
\end{tabular}

Source: ASK (Economic Statistics, series 3); CBK (Financial Newsletter 8.10).

Figure 1. Trend of the main indicators of the economy of Kosovo during the period 2006-2012

A

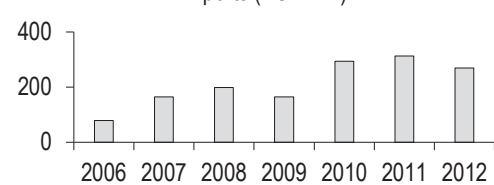

$\mathrm{C}$

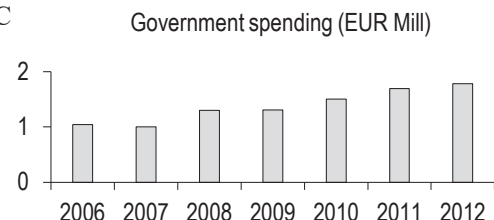

E

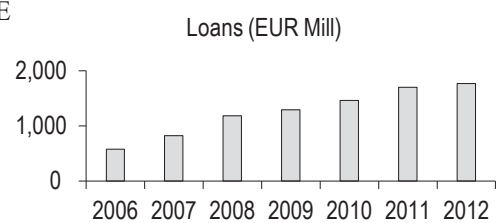

B

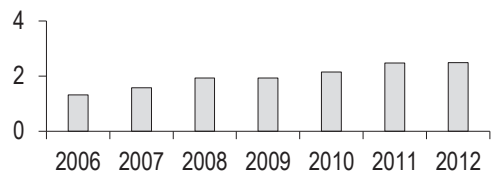

B Inflation (annual average\%)

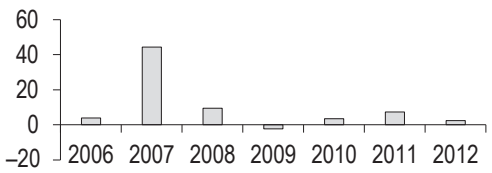

$\mathrm{F}$

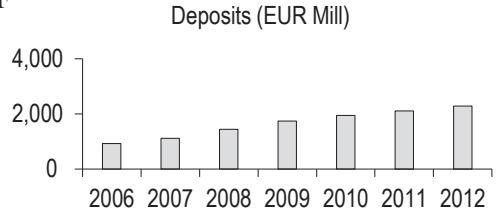

G Real growth of GDP (\%)

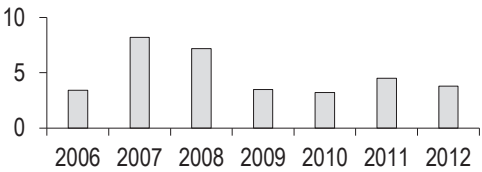

Source: ASK (Economic Statistics, series 3); CBK (Financial Newsletter 8.10).

An analysis of the real growth of Gross Domestic Product (GDP/GDP) shows that Kosovo's economy has suffered economic decline, particularly after year 2007. The main factors that have contributed in slowing of economic development are: the decrease in 
the level of exports, growth in imports, the decrease in Foreign Direct Investment and in remittances.

Moreover, the increase in spending and continued investments in the public sector, as Table 1 shows, have had a positive effect on economic growth for the period analyzed 2006-2012, and in decrease of the effect of the global financial crisis. Kosovo's economy is one of the few economies that managed to have a positive growth during the crisis. It should be noted that the global financial crisis has had a very low level impact on the banking sector in Kosovo. The positive rate of economic growth is expressed by the trend in Figure 1, showing that the real growth rate of GDP during 2006-2012 has been positive. This trend is also confirmed by loan and deposit growth, compared with the region, where only Kosovo and Albania, in 2009, had an increase in loans and deposits (Table 2).

Table 2. The growth rate of loans and deposits during the year $2009(\%)$

\begin{tabular}{|l|c|c|c|c|c|c|}
\hline \multicolumn{1}{|c|}{ Places } & Kosovo & $\begin{array}{c}\text { Bosnia \& } \\
\text { Herzegovina }\end{array}$ & Croatia & Montenegro & Albania & Macedonia \\
\hline Loans & 13.2 & -1.4 & -0.5 & -9.9 & 12.1 & 14.5 \\
\hline Deposits & 17.3 & -7.6 & -0.3 & -18.3 & 58 & -0.3 \\
\hline
\end{tabular}

Source: Financial Newsletter No. 10, 2010, CBK.

Figure 2. The growth rate of loans and deposits during the year 2009 (\%)

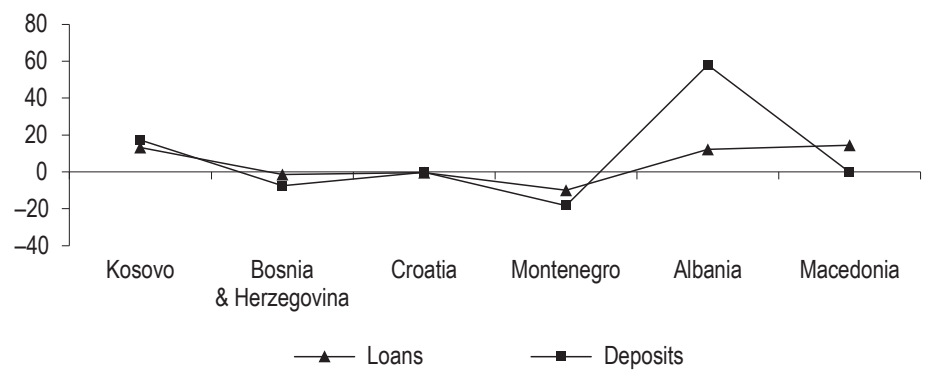

Source: Financial Newsletter No. 10, 2010, CB.

During the financial crisis, banks in Kosovo were more conservative and this caused the slowdown of lending in the economy, although the trend of lending continued to be positive. The increase of government expenditure (Table 1) during this period managed to reduce, to some extent, the negative effects of the crisis on the economy. 


\section{Research methods and assumptions}

This research uses applied descriptive analysis of financial ratios to explain the performance of commercial banks in the banking market of the Republic of Kosovo in a period of seven years $(2006,2007,2008,2009,2010,2011$ and 2012). The data for this research are secondary data ${ }^{4}$ and are taken from audited annual reports of commercial banks. All data are expressed in monetary value in Euros and are taken from the website of the Central Bank of Kosovo (CBK).

Besides classical analysis of the performance of banks for seven reporting years, the author of paper also investigates whether commercial banks are affected or not by the global financial crisis of 2008, focusing mainly on the impact of global financial crisis on the level of non-performing loans. To facilitate this analysis, bank data (financial data) were split into two aggregate groups. The first group includes the period 20062007 , before the global financial crisis, while the second group includes the period 20082009 , during the financial crisis. To see if there is a statistically significant difference in the performance of banks during 2006-2007 (group 1) compared to 2008-2009 (group 2), this research applies the student T-test. T-test was applied to test the hypothesis that the averages of these two periods are equal for all variables applied in this research.

The hypothesis in this case is zero hypothesis and can be expressed through this equation:

$$
\mathrm{H} 0: \mu 1=\mu 2 .
$$

The alternative hypothesis can be expressed through this equation:

$$
\mathrm{H} 1: \mu 1 \neq \mu 2 \text {. }
$$

The symbol $\mu 1$ shows the average of all variables for the period 2006-2007, while $\mu 2$ represents the average of all variables for the period 2008-2009. Testing the hypotheses is done by analyzing the statistical critical values, such as the value $\mathrm{T}$ and value $\mathrm{P}$ of statistical significance. The level of reliability, the ratio a applied during this test is $5 \%$. If the value $\mathrm{P} \leq \mathrm{a}$, then we must reject the zero hypothesis and accept the alternative hypothesis. If the value $\mathrm{P}>\mathrm{a}$, we must accept the null hypothesis and the alternative hypothesis should be rejected. To justify the existence of the financial crisis in the banking sector in Kosovo test results must be such that the null hypothesis is rejected.

The method for the analysis of performance and credit quality applies financial ratios. Although financial ratios are applied in most of these studies, they have not been

\footnotetext{
4 Secondary data are considered the data obtained from audited reports and are more accurate than primary data provided through surveys, where individuals surveyed are from different professional fields.
} 
used as methodological tools to measure the banking system in Kosovo for the period 2006-2012.

Financial ratios can identify the advantages and disadvantages of each bank, through the analysis of profitability and credit quality policies. Often accounting data can be subject to manipulation. Yet, for this research, the risk is eliminated due to the fact that all financial statements have been audited by licensed audit firms.

The research takes into account five commercial banks which have operated in the banking market during the period 2006-2012. All commercial banks operating in Kosovo were part of the sample, except those which have started functioning during or after 2008, which is considered the year of the inception of the global financial crisis. Commercial banks analyzed in this research are: ProCredit Bank (PCB), Raiffeisen Bank (RZB Group), Bank for Business (BPB), Economic Bank (EB), and Nova Ljubljanska Banka (NLB). Excluded from the sample of banks are: National Commercial Bank (NCB), Turkish Economy Bank (TEB) and İş Bank. Their inclusion would cause inconsistencies in the statistical analysis of the impact of the financial crisis in the banking sector in Kosovo.

Variables analyzed

Performance of profitability (profit-flow)

Based on the numerous works of different authors, we come to the conclusion that one of the best tools to measure the performance of commercial banks is profitability analysis. The main ratios for measuring the performance of profitability (profit-flow) are:

1. Return on Assets ROA = net profit/total assets. From the banking perspective this ratio indicates management's ability to attract deposits at a reasonable cost and their investment in profit-making forms. This ratio shows how much net profit is generated for every $€ 1$ of bank assets. The higher the ROA is, the more profitable the bank is. This ratio indicates how well the bank's assets are managed in order to maximize returns.

2. Return on Equity ROE = net profit/total equity. From the banking perspective, this ratio is the best indicator of profit-flow and potential for growth. Return on Equity represents the rate of return to shareholders of the bank, which is the percentage of profit for every 1 euro invested in the bank by shareholders.

3. The ratio of costs to income $\mathbf{C} / \mathbf{I}=$ Total cost/total revenues. From the banking perspective, this ratio shows how much it costs to a bank to produce a unit of output (revenue, profit). The lower the $\mathrm{C} / \mathrm{I}$ ratio, the higher the performance of the bank. 


\section{Loan Performance (Loan quality)}

In banking, all banks in one way or another expect to have non-performing loans during the course of their credit activity. However, one of the main objectives of banks is to minimize such losses. Loan performance evaluates the risk associated with bank asset portfolios, i.e. the quality of loans. One of the main ratios for measuring loan performance is Loan Loss Provision to Gross Loans (LLPGL) - reserve for non-performing loans/ gross loans. ${ }^{5}$ This ratio measures the quality of the bank loans. The higher this ratio, the more problematic the bank loans are.

\section{Results of analysis}

\section{Performance Analysis}

Performance of profitability (profit-flow)

According to studies conducted by audit companies, lending with high margin to high-risk clients, can increase profits (in short term), but this increases the risk of bank creditors and potential future losses.

Figure 3 showns the performance of profitability (profit-flow) of the banking sector in the period 2006-2012. Profit-flow was measured with ratios ROA, ROE and Cost to Income $(\mathrm{C} / \mathrm{I})$.

Table 3. The trend of profit-flow during 2006-2012 (\%)

\begin{tabular}{|l|r|r|r|r|r|r|r|}
\cline { 2 - 8 } \multicolumn{1}{c|}{} & 2006 & 2007 & 2008 & 2009 & 2010 & 2011 & 2012 \\
\hline Average ROA & -1.1 & 3.4 & 2.3 & 1.4 & 1.7 & 1.6 & 1.0 \\
\hline Average ROE & -25.3 & 25.4 & 20.1 & 13.1 & 18.6 & 17.3 & 9.6 \\
\hline Average C/I & 106.9 & 74.4 & 78.5 & 86.2 & 88.6 & 90.0 & 96.2 \\
\hline
\end{tabular}

Source: Financial Newsletter No. 10, 2010, CBK.

Figure 3. The trend of profit-flow during 2006-2012 (\%)

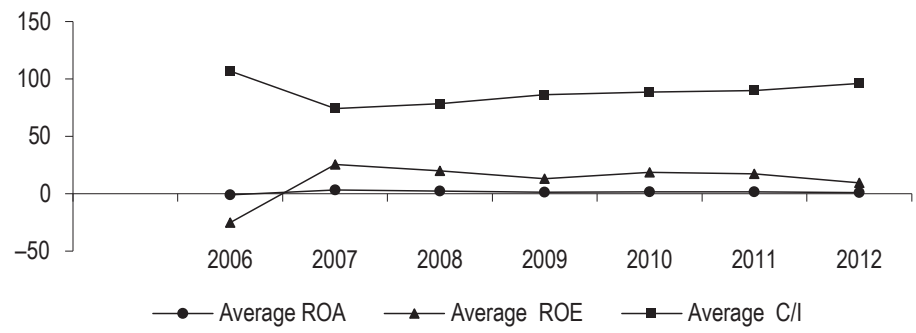

Source: Financial Newsletter No. 10, 2010, CBK.

5 Loan Loss Provision to Gross Loans. 
In Figure 3 we have an increase in the trend of profit-flow from 2006 to 2007. ROA increased from -1.1 to $3.3 \%$, while during 2008-2012 continued to fall at a slower trend, reaching $1.0 \%$ in 2012 . ROE increased from -25.4 to $25.5 \%$, while during $2008-2012$ continued to fall at a slower trend, reaching $9.7 \%$ in 2012 . The main reason for the increase of profit-flow during the period 2006-2007 is as result of the increase in the total banking sector assets, mainly on the account of loans granted to customers. A simple increase in assets does not lead to more profit. Therefore margins have to be higher or banks provisioned less.

\section{Analysis for period 2008-2009}

There is direct reflection in the profit made by commercial banks as a result of the reduction in the lending activity of the banking sector during the period 2008-2009. Compared with 2008, the net profit of the banking sector in 2009 registered a decline of $37.7 \%$, marking the value of 18.3 million euros. The decline in profit was mainly due to the slowdown in income levels of commercial banks. As a result of reduction of revenues, there was a reduction in banking sector profitability as expressed through the ROE indicator for 2009 which is significantly decreased compared to the previous year, marking the level of $20.2 \%$. The main contributor to the decline of profit-flow during 2008-2009 was the slowdown in interest income. Reducing the profit of the banking sector, lower efficiency leads to lower profit. In this context, the average return on assets (ROA) of the banking sector for 2009 was reduced to $1.5 \%$ (from $2.3 \%$ in 2008 ) could be interpreted as lower efficiency of the banking system to realize a profit from use of available assets.

\section{Analysis for period 2010-2012}

During year 2011 we noted that there is decrease of profit-flow indicators, compared with year 2012. This resulted because the banking system reported the net profit in the amount of 14.9 million euros, which is about $13 \%$ lower than in year 2010 . However, the rapid increase of costs in relation to total revenues of the banking system led to a decrease of the net profit. This can be explained by the trend of costs to income $(\mathrm{C} / \mathrm{I})$ presented in Figure 1D. Here we can notice a constant increase from 2008 to 2012 . This ratio was $74 \%$ in 2008 and was $90 \%$ in year 2012 .

Kosovo's banking system in year 2012 reported a profit of 10.2 million euro, which is $31.2 \%$ lower than in year 2011. Nevertheless, the fast growth of spending in relation to total revenues of the banking system led to a decrease of net profit (see the trend C/I in Figure 1C). Reduction of net profit in year 2012 was reflected in the deterioration of profitability indicators of the banking system (ROA, ROE, C/I). In year 2012, ROA declined, dropping to $1.0 \%$ compared with $1.7 \%$ in year 2011 . The decline impacted the 
ROE rate as well, which fell to $9.7 \%$ compared with $17.4 \%$ in year 2011 . The faster growth in spending compared to revenue in the domestic banking system has resulted in deterioration of efficiency indicators for the banking system. The ratio between costs and revenues rose $96 \%$ in year 2012 from $90 \%$ in year 2011 .

Credit performance

Credit performance is related with the level of risk associated with the loan portfolio of banks. The trend of provisions for losses on loans to gross loans during the examined period of years 2008-2012 is presented in Table 4.

Table 4. The trend of credit quality during period of years 2006-2012 (\%)

\begin{tabular}{|l|c|c|c|c|c|c|c|}
\cline { 2 - 8 } \multicolumn{1}{c|}{} & 2006 & 2007 & 2008 & 2009 & 2010 & 2011 & 2012 \\
\hline Average LLPGL & 3.9 & 3.4 & 3.5 & 4.6 & 5.8 & 4.8 & 5.9 \\
\hline
\end{tabular}

Source: Test results t-Student.

Figure 4. The trend of credit quality during period of years 2006-2012

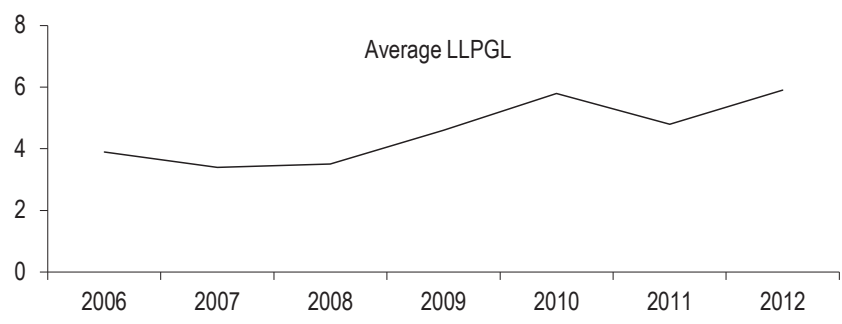

Source: Test results t-Student.

Regarding Reserve loans to gross loans during the years 2006, 2007 and 2008, there was a stable trend. During year 2011 we observed improvement of the ratio that was the result of continued growth in the level of credit and declining level of non-performing loans.

Non-performing loans increased from 3.5 to $4.7 \%$ and 5.8\% from 2008 to 2009 and 2010. The increase in non-performing loans could also be seen as a result of the impact of the global financial crisis and difficult environment in the Kosovo market. This happened due to the fact that banks were more exposed to increased credit risk, since loans with higher risk which were issued during years 2005-2006 began to deteriorate, as a result, the bank had to report to higher provisions for potential losses from these loans. 
Banks have continuously been under pressure in 2009 and beyond, as evidenced by the increase in reserves for bad loans and declining profit-flow levels, which resulted in damage to the quality of the bank loan portfolio during years 2008-2012.

Testing the hypothesis

To examine whether the difference in the performance of banks during the 20062007 period (according to statistics) is different to 2008-2009 period, the Student T-test was applied to test the hypothesis of whether the ratios of these two periods are the same for the three variables discussed and analyzed above. The following table presents the results of the T-test for both periods analyzed.

Table 5. Test results t-Student (period 2006-2007 and 2008-2009)

\begin{tabular}{|l|c|c|c|c|}
\cline { 2 - 5 } \multicolumn{1}{c|}{} & \multicolumn{3}{c|}{ Performance of Profitability } & Credit quality performance \\
\hline Average 2006-2007 (\%) & 1.11 & 17.52 & 80.77 & 3.64 \\
\hline Average 2008-2009 (\%) & 1.79 & 16.75 & 82.49 & 3.98 \\
\hline Value P & 0.3916 & 0.5398 & 0.4704 & 0.4317 \\
\hline Alfa & 0.05 & 0.05 & 0.05 & 0.05 \\
\hline The decision on the hypothesis & Accepted & Accepted & Accepted & Accepted \\
\hline
\end{tabular}

Source: Test results - t-Student.

Regarding profitability, ROA ratio indicates that banks have performed better during 2008-2009 than during 2006-2007, while in terms of ROE ratio and C/I banks have performed worse during the period 2008-2009 compared with the period 2006-2007. As presented in Table 5, the average of ROA for the period 2006 to 2007 was $1.11 \%$ compared with $1.79 \%$ for the period 2008-2009. ROE shows different trend, with an average of $17.52 \%$ during the period 2006-2007 compared to $16.75 \%$ during the period 2008-2009. Average of ratio C/I during the pre-crisis period was $80.77 \%$ and $82.49 \%$ during the crisis. All this shows that banks had better performance of profit-flow before the global financial crisis than during the global financial crisis (2008-2009). Value P for ratios $\mathrm{ROA}, \mathrm{ROE}$ and $\mathrm{C} / \mathrm{I}$ are: $0.3916,0.5398$ and 0.4704 , so the difference between profit-flow performance for the periods before crisis and during crisis is not statistically significant, since values $\mathrm{P}$ is higher than value alpha 0,05 (confidence level). According to these values, the null hypothesis should be accepted, and this means that profit-flow rate is not changed and the financial crisis did not have a very important impact on the banking sector. During year 2006 ROA was negative as a result of very poor performance of one of the commercial banks in Kosovo. This ratio is presented in Annex 2. 
In terms of the quality of loans, the average loan reserve to gross loans was $3.60 \%$ during the period 2006-2007 and 3.98\% for years 2008-2009, which shows that quality of the portfolio deteriorated during the crisis. However, this difference is not statistically significant because $\mathrm{P}$ value of this ratio is 0.4317 . Thus, the null hypothesis cannot be rejected.

From the results of the student T-test, one could argue that despite the financial crisis and its effects on the economies of many countries in the world, the Kosovo banking sector has not seen any difference or statistically significant difference between the period prior to the crisis in 2006-2007 and the crisis period 2008-2009.

This result could be explained by the fact that Kosovo's commercial banks had no direct exposure to sub-prime credit markets, while the branches of international banks had a very limited exposure to them.

\section{Conclusion and discussion}

The main purpose of this paper was:

1. Analyzing the performance of commercial banks in Kosovo, and analyzing credit quality mainly based on growth trends in non-performing loans in the banking sector.

2. Thus, this research measured the quality of loans and profitability of the banking sector of commercial banks in Kosovo during the period 2006-2012 and tested, statistically, the level of impact of the global financial crisis in these banks. The evidence shows that in general, profit-flow, liquidity and credit quality have improved over the years 2006 to 2008, and from 2008 began to become progressively worse.

3. In line with the survey results, we can conclude that there was no significant difference from statistical perspective in the overall performance of the banks, including the measurement of profitability and the quality of loans during the period 2006-2007 compared with 2008-2009. This might have occurred due to the fact that Kosovo faced with the global financial crisis while having a good macro-fiscal position, allowing for smaller impact.

4. We can conclude that the banking sector in Kosovo has remained stable despite the appearance of disturbances and the crises in global financial markets during 2008-2009. In terms of capital adequacy and the acceptable level of liquidity, banks have continued to meet all regulatory requirements. Also, it can be said that banks have remained in stable position and have been protected from the adverse effects of the global financial crisis, as they have benefited from limited exposure 
to foreign securities and from the fact that the assets of the crisis have been minimal in balance sheets of Kosovo commercial banks.

\section{Annex}

\section{Annex 1 -Detailed Data for Test t-Student}

Test results-t: ROA

\begin{tabular}{|l|c|c|}
\cline { 2 - 3 } \multicolumn{1}{c|}{} & $2006-2007$ & $2008-2009$ \\
\hline Average & $1.112 \%$ & $1.799 \%$ \\
\hline Variance & 0.00034762 & 0.53375 \\
\hline Observations & 5 & 5 \\
\hline Pearson Correlation & 0.282200343 & \\
\hline Hypothesized Mean Difference & 0 & \\
\hline Df & 4 & \\
\hline $\mathrm{t}$ Stat & -0.959394489 & \\
\hline $\mathrm{P}(\mathrm{T} \leq \mathrm{t})$ two-tail & 0.391689699 & \\
\hline $\mathrm{t}$ Critical two-tail & 2.776445105 & \\
\hline
\end{tabular}

Test results-t: ROE

\begin{tabular}{|l|c|c|}
\cline { 2 - 3 } \multicolumn{1}{c|}{} & $2006-2007$ & $2008-2009$ \\
\hline Average & $17.57 \%$ & $16.85 \%$ \\
\hline Variance & 0.015204425 & 123.59875 \\
\hline Observations & 5 & 5 \\
\hline Pearson Correlation & 0.905870193 & \\
\hline Hypothesized Mean Difference & 0 & \\
\hline Df & 4 & \\
\hline $\mathrm{t}$ Stat & 0.670240248 & \\
\hline $\mathrm{P}(\mathrm{T} \leq \mathrm{t})$ two-tail & 0.539412956 & \\
\hline $\mathrm{t}$ Critical two-tail & 2.776445105 & \\
\hline
\end{tabular}

Test results $-\mathrm{t}: \mathrm{C} / \mathrm{I}$

\begin{tabular}{|l|c|c|}
\cline { 2 - 3 } \multicolumn{1}{c|}{} & $2006-2007$ & $2008-2009$ \\
\hline Average & $80.77 \%$ & $82.49 \%$ \\
\hline Variance & 0.05358845 & 0.002526925 \\
\hline Observations & 5 & 5 \\
\hline Pearson Correlation & 0.087918649 & \\
\hline Hypothesized Mean Difference & 0 & \\
\hline Df & 4 & \\
\hline t Stat & 0.796233356 & \\
\hline $\mathrm{P}(\mathrm{T} \leq \mathrm{t})$ two-tail & 0.470479565 & \\
\hline $\mathrm{t}$ Critical two-tail & 2.776445105 & \\
\hline
\end{tabular}


Test results - t: LLPGL

\begin{tabular}{|l|c|c|}
\cline { 2 - 3 } \multicolumn{1}{c|}{} & $2006-2007$ & $2008-2009$ \\
\hline Average & $3.60 \%$ & $4.04 \%$ \\
\hline Variance & 0.89 & 1.19325 \\
\hline Observations & 5 & 5 \\
\hline Pearson Correlation & 0.454862942 & \\
\hline Hypothesized Mean Difference & 0 & \\
\hline $\mathrm{Df}$ & 4 & \\
\hline $\mathrm{t}$ Stat & -0.793822978 & \\
\hline $\mathrm{P}(\mathrm{T} \leq \mathrm{t})$ two-tail & 0.471732298 & \\
\hline $\mathrm{t}$ Critical two-tail & 2.776445105 & \\
\hline
\end{tabular}

Annex 2 - Data of financial ratios 2006-2012

\begin{tabular}{|c|c|c|c|c|c|c|c|}
\hline Ratio/Bank & 2006 & 2007 & 2008 & 2009 & 2010 & 2011 & 2012 \\
\hline \multicolumn{8}{|l|}{ a) ROA (\%) } \\
\hline BPB & -12.5 & 8.6 & 3.0 & 0.7 & 0.8 & -0.8 & -1.9 \\
\hline PCB & 1.8 & 2.9 & 2.9 & 3.0 & 2.9 & 2.3 & 2.4 \\
\hline RBKO & 2.8 & 3.4 & 2.5 & 1.1 & 1.2 & 1.8 & 1.9 \\
\hline NLB & 1.4 & 1.3 & 1.7 & 1.3 & 1.3 & 1.1 & 1.1 \\
\hline $\mathrm{BE}$ & 1.2 & 0.6 & 1.2 & 0.7 & -0.5 & 0.1 & -1.9 \\
\hline Average & -1.1 & 3.4 & 2.3 & 1.4 & 1.1 & 0.9 & 0.3 \\
\hline Ratio/Bank & 2006 & 2007 & 2008 & 2009 & 2010 & 2011 & 2012 \\
\hline \multicolumn{8}{|l|}{ b) ROE (\%) } \\
\hline BPB & -201.8 & 50.4 & 20.8 & 5.5 & 6.4 & -8.0 & -28.4 \\
\hline РCB & 30.8 & 39.2 & 36.9 & 34.9 & 29.2 & 21.0 & 19.5 \\
\hline RBKO & 24.4 & 24.9 & 20.6 & 8.9 & 11.1 & 12.7 & 12.1 \\
\hline NLB & 10.3 & 10.5 & 14.3 & 11.8 & 12.5 & 11.4 & 11.1 \\
\hline BE & 9.5 & 2.9 & 8.5 & 5.3 & -5.4 & 1.8 & -25.6 \\
\hline Average & -25.4 & 25.6 & 20.2 & 13.3 & 10.8 & 7.8 & -2.3 \\
\hline Ratio/Bank & 2006 & 2007 & 2008 & 2009 & 2010 & 2011 & 2012 \\
\hline \multicolumn{8}{|l|}{ c) $\mathrm{C} / \mathrm{I}(\%)$} \\
\hline BPB & 209.9 & 50.7 & 70.5 & 93.4 & 97.6 & 107.4 & 119.4 \\
\hline PCB & 82.6 & 73.6 & 76.4 & 73.1 & 74.0 & 78.9 & 77.4 \\
\hline RBKO & 72.2 & 72.0 & 78.5 & 89.4 & 83.1 & 79.5 & 79.8 \\
\hline NLB & 82.3 & 83.1 & 82.3 & 85.1 & 84.8 & 85.6 & 84.9 \\
\hline $\mathrm{BE}$ & 87.4 & 94.7 & 85.9 & 91.4 & 103.2 & 98.6 & 119.7 \\
\hline Average & 106.9 & 74.8 & 78.7 & 86.5 & 88.5 & 90.0 & 96.2 \\
\hline Ratio/Bank & 2006 & 2007 & 2008 & 2009 & 2010 & 2011 & 2012 \\
\hline \multicolumn{8}{|l|}{ d) LLPGR (\%) } \\
\hline BPB & 3.1 & 3.2 & 3.2 & 6.1 & 7.1 & 6.2 & 6.2 \\
\hline PCB & 2.4 & 2.5 & 3.7 & 3.9 & 4.2 & 5.1 & 5.6 \\
\hline RBKO & 4.3 & 2.2 & 1.6 & 2.7 & 3.9 & 4.2 & 9.1 \\
\hline NLB & 4.6 & 4.7 & 4.5 & 5.1 & 4.2 & 0.0 & 0.0 \\
\hline $\mathrm{BE}$ & 4.5 & 4.5 & 3.8 & 5.2 & 8.6 & 8.3 & 8.2 \\
\hline Average & 3.8 & 3.4 & 3.4 & 4.6 & 5.6 & 4.8 & 5.8 \\
\hline
\end{tabular}




\section{References}

Altman, E.I. (1986). Financial ratios, discriminant analysis and the prediction of corporate bankruptcy. The journal of finance 23 (4), 589-609.

Beaver, W.H. (1966). Financial ratios as predictors of failure. Journal of accounting research, 71-111.

Berger, A.N., Humphrey, D.B. (1997). Efficiency of financial institutions: international survey and directions for future research. European Journal of Operational Research, 98, 175-212.

Bernanke, B., Gertler, M. (1989). Agency costs, net worth, and business fluctuations. The American Economic Review, 79 (1), 14-31.

Bonin, J.P., Hasan, I., Wachte, P. (2005). Bank perfomance, efficiency and ownership in transition countries. Journal of Banking \& Finance 29 (1), 31-53.

Casu, B., Molyneux, P. and Girardone, C. (2006). Introduction to Banking, Prentice Hall/ Financial Times, London.

Central Bank of Kosovo (2011, 2012) Financial Stability Report No. 10, 1, $2,3$.

Central Bank of Kosovo CBK (2010). Statistical Newsletter No. 10.

Cukierman, A., Web, S.B., Neyapti, B. (1992). Measuring the independence of central banks and its effect on policy outcomes. The World Bank Economic Review, 6 (3), 353-398.

Demirguc-Kunt, A., Huizinga, H. (1999). Determinants of commercial bank interest margins and profitability: Some international evidence. The World Bank Economic Review, 13 (2), 379-408.

Foreign Trade Statistics (2013). Economic Statistics (series 3, ASK).

Grigorian, D.A., Manole, V. (2002). Determinants of commercial bank performance in transition: An application of data envelopment analysis. No. 2002-2146, International Monetary Fund.

Kirkpatrick, C., Murinde, V., Tefula, M. (2007). The measurement and determinants of $\mathrm{x}$-inefficiency in commercial banks in Sub Saharan Africa. European Journal of finance, 14 (7) 2, 625-639.

Kiyota, H. (2009). Efficiency of commercial banks in Sub-Saharan Africa: A comparative analysis of domestic and foreign banks (No. 2011, 58). Working paper//World Institute for Development Economics Research.

Kosovo Commercial banks' annual reports for the periods 2006-2012.

Lonneke, M. (2005). Predicting bankruptcy with discriminant analysis and decision tree using financial ratios. University of Rotterdam.

Luboteni, G. (2007). Corporate Finance: textbook. Dukagjini, Prishtina.

Maishanu, M.M. (2004). A univariate Approach to Predicting failure in the Commercial Banking Sub-Sector in Nigerian Journal of Accounting Research, 1 (1), 76.

Ncube, M. (2009). Efficiency of the Banking Sector in South Africa, African Economic Conference 2009. Fostering Development in an Era of Financial and Economic Crises, Addis Ababa.

Oral, M., Yolalan, R. (1990). An empirical study on measuring operating efficiency and profitability of bank branches. European Journal of Operational Research 46 (3), 282-294.

Tarashev, N. (2010). Measuring portfolio credit risk correctly: Why parameter uncertainty matters. Journal of Banking \& Finance, 34 (9), 2065-2076.

Tarawneh, M. (2006). A Comparison of Financial Performance in the Banking Sector: Some Evidence from Omani Commercial Banks. International Research Journal of Finance and Economics, 3, 103-112. 
Web, R.M. (2003). Levels of efficiency in UK retail banks: a DEA window analysis. International Journal of the Economics of Business, 10 (3), 305-322.

bqk-kos.org/repository/docs/2011/Raporti\%20Vjetor\%202010.PDF.

\section{Abstract}

This research evaluates the performance of commercial banks in Kosovo, including the structure of nonperforming loans in the Kosovo banking system. The main findings in this paper come from the three largest banks in Kosovo, indicating no significant statistical difference between them.

The other findings come from two smaller banks in Kosovo, indicating that their situation has started deteriorating after the global financial crisis.

The research is based on financial indicators of commercial banks. These indicators results are available in their financial statements published annualy on banks websites from 2006 to 2012.

The loan portfolio in Kosovo commercial banks is identified as highly important - the main source of income in the sector. However, the loan portfolio is also the main source of financial risk and bank's reputation.

The paper is organized around five sections.

- Section 2 provides literature review on the performance of banks in other countries,

- Section 3 provides an analysis of the banking sector in Kosovo and the macroeconomic indicators during the period analyzed,

- Section 4 presents the results of analyzing the financial ratios,

- Section 5 presents financial analysis and provides key conclusions,

- Section 6 presents an overview of the research and provides the main conclusions. 